\title{
THE EVOLUTION OF CINEMATOGRAPHY IN RUSSIAN LITERATURE OF THE 1920S
}

\author{
Valentina A. Nikolaeva ${ }^{1}$ \\ Natalia L. Fesyanova ${ }^{2}$ \\ Olga N. Goryacheva ${ }^{3}$
}

\begin{abstract}
This paper concerns the issue an innovative character to the works, of the interaction of literature and cinematography in the cultural process of the 1920s. The main emphasis is placedon the phenomenon of literary cinematography, which became widespread in the third decade of the 20th century. The content of the concept of "cinematographic literature"is defined, its significant characteristics are develop new ways of constructing the plot. In addition, cinematography makes it possible to add the text documentary and agitationality. The study revealed a close relationship between the development of cinematography in the literature and the general tendencies of the cultural process of the early 20th century.
\end{abstract} singled out (special compositionalsyntactic organization of the work, representation of the situation of observation, the use of cinema

Keywords: synthesis of arts, literary cinematography, LEF, Russian literature of the 1920 s.

techniques) and the development of cinematography in the work of poets and writers of the period is studied. Inthecourseof the analysis of thetexts, specific techniques and cinematographic functions characteristic of this decade were singledout. Experimenting with artistic time and space, the authors attach

\section{Introduction}

A tendency to the synthesis of arts was a characteristic feature of the culture of the late 19th - early 20th centuries. With the help of such connection, the authors of the works

\footnotetext{
${ }^{1}$ Kazan Federal University, Naberezhnye Chelny Institute. E-mail: valentinka.n@mail.ru tel. 89600727320.

${ }^{2}$ Kazan Federal University, Naberezhnye Chelny Institute.

${ }^{3}$ Kazan Federal University, Naberezhnye Chelny Institute
} 
attempted to solve a number of problems: from the creation of innovative techniques to the formation of the theories devoted to the global transformation of society. This process was continued in the 1920 s, when the visual arts began to attract a keen interest, including cinematography, which wasgoing through anupsurge in development in that period.

The possible and realized interaction of cinema and literature was discussedby both the figures of the first third of the 20th century and contemporary researchers. So, in 1927 the collection "The Poetics of Cinema" [1] covering the specificity of cinematography and its correlation with other art forms, especially with literature,was published.In the beginning of the 21 st century N.A.Khrenov printed the work "Cinema: Rehabilitation of Archetypical Reality" [2], studying the history of the development of cinematography in the cultural aspect, taking into account the beginnings of rise and influence on the historical and cultural process.

A number of works dealing with the impact of film art on artistic literaturehave been created. These are the large-scale studies that determine the essence of the concept of "cinematographic literature" [3], and the proceedings whichanalyze the works of certain authors $[4,5]$. But the problem of the literature-cinema relationship cannot be called fully studied, since there are the questions having not been considered individually. The latter concern the development of cinematography in the Russian literature of the 1920s.

\section{Methods}

Poetic and prose works of literature, articles and creative manifestos of the 1920s were used as an empirical basis. The structuraltypological method enabled to study the specificity of cinematographic manifestations in literary texts, to definethe specific techniques and principles.

Also, the study is based on comparative historical and culturological methods that help to consider the interaction of literature and cinema in thecontext of culture, to single out the tasks and causes of such relationship within a certain historical period.

\section{Results and Discussion}


Interest in cinematography in the $1920 \mathrm{~s}$ was associated in many respects with its great advance in development. Until now, cinema has often been perceived as something imperfect: the result of a joint influence of literature and theater, "light" booth, etc. [6]. By the third decade of the twentieth century, cinema has acquired its own language, specific techniques and has been finally recognized as an independent type of art [7], which cannot only conceive the features of painting, literature, etc., but also influence them.

The collection "The Poetics of Cinema", the authors of which, among other things,drew a parallel between literature and cinema, made the idea of the proximity of these arts particularly popular. Most often they argued about the similarity of cinema and poetry - the division of the text into lines was compared with the filmshot change. Many writers and poets deliberately included the elements of cinema in the piecesof art, created related genres (the poem was called "a lyric film", a travel essay -“the path of a film", etc.). There was a plunge into the world "behind the screen": for example, in the poem by N. N. Aseev "Bomb" the story of a soldier, designated as a literary work («Как тиф начинается стих» / "The verse begins like" [8, p. 49]).turned into the film with credit titles. In some cases, it was just following "the fashion", but more often than not synthetic searches helped the authors to solve intellectually demanding tasks in a new way.

First of all, it is necessary to clarify the content of the concept of "cinematographic literature". Already in the mid-1920s. there appears the term "cinema-literature" [9], implying the works of literature, created under the influence of the cinema. The main feature of these texts was the striving for the dynamism of the narrative. Modern researchers consider this phenomenon not so categorically. Cinematic is considered to be a work, in which a set of features is inherent, which is characteristic even of cinema. It does not matter whether the author wanted to make his text this way or he made it unconsciously - it is significant how the work isconstructed. First of all, it will differ by a specific compositionsyntactic organization. The text is often divided into small paragraphs. The author of such work aims not so much at giving a detailed description of the artistic world, butforming an impression of it with the help of a number of vivid 
figures and details. Separate elements are connected by editing $[3,4,10]$. Another important principle of cinematographic literature is its visualityset. The text does not just seem "visual" - the narrative is organized as a mix or alternation of the points of view of specific characters watching what is happening. And this observation must go on in motion [3, 4]. As a result, artistic time and space in the cinematographic work attract attention, they are formed and written with special care and allow of doing creative experiments. And the most obvious feature of literary cinematography is an attempt to carry over its specific methods of cinema into the literary sphere.

These features are in many respects not unique. So, the montage was quite widespread in the literature of the turn of the 19th-20th centuries $[10,11]$. In the 1920s. thisdevicehadbeen still relevant. The creation of a single picture from disparate elements becomes an important part of the cultural process on the whole.Itis reflected in the cinematography, which in the 1920swas called“editing" in photo art, in painting, etc. N. A. Khrenov, studying the role of film montage in the cultural space of the third decade of the 20th century, comes to the conclusion that the cinema helps to form a new artistic norm; the editing narrative principle begins to be perceived as something ordinary. Thus, cinema influences literature, but this dependence is not direct, but indirect [2, p. 203-204].A tendencyto dynamism in literature was also developed independently, especially in the creative work of the futurists who tried to reflect the rhythm of modernity and the movement towards the future. That is, separately taken elements of cinematography existed in the literature before, moreover, they received special development in the art of the beginning of 20th century in general. But the cinematography contributed to their dissemination, popularization. Thanks to the influence of the cinema, thereappeared the texts, where these characteristics are concentrated, intertwined, and therefore cinematographic works differ from the usual, more traditional ones.

The mutual influence of cinema and literature is already in the Silver Age, for example, the reception of "pullback"was repeatedly reflected in the works of the early twentieth century. In the 1920 s this interaction comes to a new level. The poets, writers try to find original ways of creating text, and the 
cinema becomes a source of inspirationfor many of them. This process was most vividly carried out within the framework of the LEF activities.

LEF is a literary group created by former futurists who continue to develop the creative principles of the current under new historical and cultural conditions. The works of the futurists reflected largely the cinematic characteristics: their literary texts were montage, dynamic, which was noted by both researchers and authors of futurist manifestos $[12,13,14]$. In the 1920slefs declare the need to strengthen the innovative component of works by creating new ways of plotting $[15,16]$. The members of the association define a spatio-temporal organization being characteristic of cinematography as their orientation. Literary texts created according to new principles are published in the journals of the association -"Lef" and "New Lef". Not only the works of Lef are printed, but also poetry and prose of other authors, corresponding to the views of the literary group (for example, the texts of $\mathrm{V}$. P.Kataev, I. E. Babel, L. A.Kassil, etc.) i.e. the process of creating cinematic literature was not restricted to the activities of the association, many poets and writers were engaged in it.

As an example of a text of a new type, one can analyze the novelby B.A. Kushner «Незатухающие колебания»/ "Undamped Oscillations". The main principle of the organization of the work is editing one, and there are combinednot only different events, stories, but also the points of view of the characters and the narrator. The novel begins with a description of the placeobserved through the wire fence:

«Ниже шоссе кольцом обегало гору белое, серое, пыльное, как новая автомобильная камера.

Еще ниже переплелись колеи железной дороги.<...>

Русские окопы были за рекой» [17, p. 55]. I

"A mountain was enclosed by the highway below with the ring - white, gray, dusty, like a new car camera.

Even lowerthe railroad tracks interwove. $<\ldots>$

Russian entrenchments were beyond the river"

The picture is presented in three dimensions, but it is limited by the narrator, the part of it disappears of sight 
(for example, it is stressed that it is impossible to see the further way of the car speeded by). Then, without an obvious switch, the escape of the captured soldiers is described, which are the observers in the first lines of the text (and this fact becomes clear only through the repetition of the phrase, there are no the authors' comments on this matter). The novel is a combination of three different storylines, and the switch from one story to another is rather original:

«Врач не знал, умирать ли раненному или нет. И сам раненый не знал этого. $<\ldots>$

Лежал неподвижно. Плечо, разбитое бревном, набухло, как подушка.

Видел удивительные вещи.

Видел Тиргартенштрассе. Асфальт, отполированный шинами двадцати тысяч городских автомобилей. <..> Ганс Рабе шел по мягкой дорожке под деревьями вдоль асфальтовой реки...»[17, p.68-69]

"The doctor did not know whether a wounded person to die or not. And the wounded himself did not know this. <...> He was lying motionless. The shoulder, broken by a log, swelled like a pillow. I saw amazing things.
I saw the Tiergartenstrasse. The asphalt, polished with tires of twenty thousand city cars. $\langle\ldots\rangle$

Hans Rabewas walking along a soft path under the trees along the asphalt river ..."

The reader, through the eyes of a wounded soldier, redirects his attention to the events from the life of a new character. This description resembles a cinematic fade-in, when through one picture gradually appearsanother one. In this case, the transition is mechanical, it is just an unusual change of place of action, aconnection between the characters is not justifiedlogically. This is not a recollection of the past, not a fantasy and not a dream - the further narrative is connected with the story of the revolutionary, to be the most meaningful in the work. All parallels between the story lines are associated with visual images:«Чугунная решетка сада ничего не мешает видеть, как не мешали проволочные заграждения видеть весь путь от австрийских окопов до русских»[17, p.62]/ “Тhe cast-iron lattice of the garden does not preventfrom seeing like the wirefences did not prevent from seeing all the way from the Austrian trenches to the Russian 
ones". The narrative turns out to be abrupt, the narrator draws scattered pictures of the observation of the characters, the juxtaposition of which should lead the reader to the author's idea. The attempt to escape from captivity to freedom, to find the lost beloved in a foreign city, to help people getting rid of the yoke of power (having arranged a strike at the factory) are all phenomena of the same order, natural desires and aspirations of a person, called "undampedoscillations".This approach was common in the movies of the 1920s. The relation to the style of the films is emphasized throughout the text: the character's look is compared with a photographic camera, cinema always attracts the character's attention, thedescriptions often resemble the scenes from popular films.

If in the "Undamped Oscillations" B. A. Kushner conducts experiments with the artistic space, then in the "The Native Land" A. Vesely focuses attention on the time, more precisely, the speed of narrating. The passage published in the journal "Lef" depicts people's festivities. The narrative consistently goes through several stages. From the beginning the reader observes the individual villagers:
«ОбедалибратьяОгурцовы.

Побросали ложки. За ворота. Вчетвером. Споленьями, стяпкой туча» [18, p.63]./“"Brothers Ogurtsovs were dining. They threw the spoons. For the gate.Four together. With logs, with a hoe - a cloud"

Then the general plan of the village is represented: «Девки, бабы, парни, мужики, ребятня. Хрусткийвизг. Хрипутробный» [18, p.64]. "Girls, women, guys, men, children. A squeal. Death-rattle". And everything flows into a general festive noise:

$\ll \mathrm{Op}$.

Буй.

Гик» [18, p.64].

After that, the chain of pictures passes the reverse "path" - and again it repeats, and so it happens throughout the text. One forms the impression that the narrative is slowed down so that you can see specific characters, then it accelerates to such an extent that the entire image becomes indistinguishable. This is way the character and the scope of the national holiday are conveyed. 
Similar techniques were used in poetic works.

In the second half of the $1920 \mathrm{~s}$ the creativity of the lefs acquires the characteristics of socialist realism, and the members of the association pay attention to other possibilities of cinematography that are applicable in the literature. Lefsneeded to form a certain point of view among the readers, and it is most naturally to do this. For this purpose, emphasis is placed on the documentary beginning. The most common genre of LEF in this period is the travel essay, which receives the symbolic designation "the path of a film" (S. M.Tretyakovin this way defined the genre of his novel "Moscow - Beijing" [19], which set a certain tone for the narrative of subsequent essays). The author has set himself the task of conveying as much detail and naturalness as he saw during the journey. The text is constructed as a sequential observation of the narrator for the surrounding, unfolded in time. Attention to specific details and at the same time the dynamic narrative, the accented description of really existing routes and familiarity with them as if in real time makethe author winthe readers, form the credibility of the text. In this case, despite the statement of the lefs that the reality is rendered as objectively as possiblein their essays, in fact a certain standpoint is represented in the works. Another essayby S. M. Tretyakov expressly determines the desire to make the reader's view more "productive" so that he immediately to draw a line between the representatives of the "old" world and the "new" one, the socialist, and to rejoice at the achievements of the latters[20, p.24].

\section{Summary}

Thus, there are several reasons for which the poets and writers of the 1920s created cinematographic works. First, the turn to the techniques of the cinema enabled to update the approach to creating aliterary text. New ways of plotting based not so much on the logic of the narrative but on visual associations, the desire to create an experimental work are being formed. The authors play with artistic time and space, include the cinema devicesin the literary text.

Second, with the help of cinematography, the documentary nature of the works is emphasized. The image of the real pictures and actions, despite 
the apparent conventionality, evokesthe sensation of reliability of the described. Documentary texts help to disguise their agitation task.

Third, attention to cinematography was largely due to the prevalence of the idea of the interdependence of literature and cinema. Writers and poets created new genres, plunged the characters into the world "behind the screen", not only their attempting to create a qualitatively new artwork, but also wanting to embody the popular trend in their work.

\section{Conclusion}

The development of cinematography in the work of the poets and writers of the 1920s. was associated with the characteristics of the literary and cultural process of the first decades of the 20th century. Attention to the visual beginning, the use of editing, the desire to convey the dynamics of the modern rhythm of life - all these are meaningful elements of different types of art, not formed under the direct influence of cinema. But the cinema, as developed, contributed to their strengthening in the culture of the 20thcentury.
It was in the 20th century when a shift from literary-centricity to the predominance of visual arts took place, which led to changes in the field of literature. The further study of the cinematography of the literature will make it possible to understand and describe this process more comprehensively.

\section{ACKNOWLEDGEMENTS}

The work is performed according to the Russian Government Program of Competitive Growth of Kazan Federal University.

\section{References}

Poetics of the Films. Theoretical Works of 1920s. - M.:Academic Project, 2016. $-497 \mathrm{p}$.

Khrenov N. A. Cinema: Rehabilitation of Archetypical Reality. - M.:Agraf, 2006. -704 p.

Martianova I. A. Cinema Century of the RussianText: Paradox of Literary Film Looking. - SP.: САГА, 2002. - 240 p.

Mozhaeva T.G. Linguistic Means of Realization of Film Looking in Literary 
Text: Based on the Works by G. Green, E. Hemingway, M. Atwood: Dissertation for Candidate of Philology. - Barnaul, 2006. - 167 p.

Cohen K. Film and Fiction: The Dynamics of Exchange. - New Haven: New York University Press, 1979. - 200 p.

Tsivian Y. Early Cinema in Russia and its Cultural Receptione. - Chicago and London: University ofChicago Press, 1998. $-273 \mathrm{p}$.

Beumers B. A History of Russian Cinema. - Oxford: Berg, 2009. - 328 p. Aseev N. Bomb // Lef. - 1923. - № 3. P. 49.

URL: http://www.ruthenia.ru/sovlit/j/2855.ht ml(Access Date: 14.08.2017).

Dynnik V., Krizhanovsky S. CinemaLiterature// Literary Encyclopedia: The Dictionary of Literary Terms. In2Volumes. - M.;L.: L.D. Frenkel Publisher, 1925. - V. 1. А-П. - Р. 348355. - URL: $\underline{\text { http://feb- }}$ web.ru/feb/slt/abc/lt1/lt1-3484.htm (Access Date: 14.08.2017).
Alqadi K. Literature and Cinema// International Journal of Language and Literature, 2015. - № 1. - p. 42-48. URL: http://ijllnet.com/journals/ij11/Vol_3_No_1_June 2015/6.pdf(accessed on: 14.08.2017).

Goody A. Technology, Literature and Culture. - Cambridge: Polity press, 2011. - 192 p.

Markov V. Futurism: A History. London: MacGibbon and Kee, 1969. $467 \mathrm{p}$.

Barooshian V. D. Russian cubo-futurism 1910-1930: a study in avant-gardism. Hague; Mouton, 1976. - 176 p.

The Russian Avant-Garde and Radical Modernism/ed. by D. G. Ioffe, F. H. White. - Boston: Academic Studies Press, 2012. - 488 p. - URL: http://www.bibliorossica.com/book.htm 1;jsessionid=F0240DE44B27A40A780C 78148D9F47C6? search_query $=$ The $+\mathrm{Ru}$ ssian+Avant-

$\underline{\text { Garde+and+Radical+Modernism\&curr }}$ $\underline{\text { BookId }=4109 \& \ln =\mathrm{ru}}($ Access $\quad$ Date: 14.08.2017). 
Lawton A., Eagle H. Russian

FuturismThrough Its Manifestoes, 1912-

1928. - Ithaca, New York: Cornell

University Press, 1988. - 355 p.

Stephan H."Lef" and the left front of the arts. - München: Otto Sagner, 1981. $242 \mathrm{p}$.

Kushner B.A.Iso-Story // Lef. - 1924. -

№ $2 . \quad-$ P.55 $-88 . \quad-$ URL:

http://www.ruthenia.ru/sovlit/j/2976.ht

ml (Access Date: 14.08.2017).

VeselyA. TheNativeLand // Lef. - 1925.

- № 3. - P. 59-69. - URL:

http://www.ruthenia.ru/sovlit/j/2991.ht

ml(Access Date: 14.08.2017).

TretiakovS. Moscow-Peking // Lef. 1925. - № 3. - P. 33-58. - URL:

http://www.ruthenia.ru/sovlit/j/2990.ht ml (Access Date: 14.08.2017).

Tretiakov S. Through Unrubbed Spectacles // NovyLef. - 1928. - № 9. -

P.20-24. URL:

http://www.ruthenia.ru/sovlit/j/3411.ht $\underline{\mathrm{ml}}$ (Access Date: 12.05.2017). 